\title{
The compound paraquat dichloride hydrate significantly affects the in vitro growth rate of a Chromobacterium violaceum wild type strain
}

\author{
O composto hidrato-dicloreto de paraquat afeta a taxa de crescimento in vitro de uma \\ cepa do tipo selvagem de Chromobaterium violaceum
}

\author{
Jane Eyre Gabriel ${ }^{1 *}$, Denise Andréa Silva de Souza², Francisco Allan Leandro de Carvalho³ ${ }^{3}$ Humberto \\ Maciel França Madeira ${ }^{4}$
}
${ }^{1}$ Professora Associada do Colegiado de Medicina, Campus Sede, UNIVASF, Petrolina, PE.; ${ }^{2}$ Doutoranda do Programa de Pós-Graduação em Biociências e Biotecnologia Fiocruz, Curitiba, PR.; ${ }^{3}$ Doutorando do Programa de Pós-
Graduação em Engenharia de Alimentos USP, Pirassununga, SP.; ${ }^{4}$ Professor Titular do Centro de Ciências Agrárias PUCPR, São José dos Pinhais, $P R$

\begin{abstract}
Introduction: the toxicity of pesticides on bacterial cell growth is still limited. Objectives: The current study aimed to assess the in vitro growth rate of the C. violaceum wild type strain ATCC12472 exposed to the herbicide paraquat dichloride hydrate at different incubation times and final concentrations. Methodology: bacterial inocula were incubated in a nutrient broth medium containing the compound paraquat at final concentrations 100 and $1.000 \mu \mathrm{g} \mathrm{mL}^{-1}$ under aeration conditions. Spectrophotometric readings at different incubation times were carried out to estimate the in vitro bacterial growth rate. Moreover, the number of viable bacteria cells in the samples was also estimated in the presence of the paraquat at two concentrations tested based on colony-forming units grown on the nutrient broth agar. Results: significant decreases in the $C$. violaceum growth rate were detected, after one hour of paraquat exposure at a final concentration of $1,000 \mu \mathrm{g} \mathrm{mL}^{-1}(p<0.05)$ compared to all treatments tested. After two hours of paraquat exposure, significant decreases were progressively found at all final concentrations of $100(p<0.01)$ and of $1,000 \mu g \mathrm{~mL}^{-1}(p<0.001)$. These data were also corroborated by counting the total number of colony-forming units at final concentrations tested. Conclusion: the findings described in current study suggest that the compound paraquat dichloride hydrate exerts significant effects on the in vitro growth rate of a $C$. violaceum wild type strain.
\end{abstract}

Keywords: Bacteria. Ecosystem. Poisoning. Toxicity.

\begin{abstract}
Resumo
Introdução: a toxicidade de pesticidas sobre o crescimento de células bacterianas ainda é limitada. Objetivos: o presente estudo objetivou avaliar a taxa de crescimento in vitro de uma cepa selvagem de C. vilaceum ATCC12472 exposta ao herbicida hidratodicloreto de paraquat em diferentes tempos de incubação e concentrações finais. Metodologia: inóculos bacterianos foram incubados em um caldo nutritivo contendo o composto paraquat nas concentrações 100 e $1.000 \mu \mathrm{gL}^{-1}$ sob condições de aeração. Leituras espectrofotométricas em diferentes tempos de incubação foram realizadas para estimar a taxa de crescimento in vitro bacteriano. Além disso, o número de células bacterianas viáveis nas amostras foi também estimado na presença do paraquat nas duas concentrações testadas, baseado no número de unidades formadoras de colônias crescidas em meio nutritivo ágar. Resultados: diminuições significativas na taxa de crescimento da $\mathrm{C}$. violaceum foram detectadas, após uma hora de exposição ao paraquat na concentração final de $1.000 \mu \mathrm{g} \mathrm{mL}^{-1}(p<0,05)$ em comparação aos demais tratamentos testados. Com duas horas de exposição ao paraquat, diminuições significativas foram progressivamente encontradas em todas as concentrações finais de $100(p<0,01)$ e de $1.000 \mu \mathrm{gLL}^{-1}(p<0,001)$. Tais dados foram corroborados pela contagem do número total de unidades formadoras de colônias nas concentrações analisadas. Conclusão: as descobertas descritas aqui sugerem que o composto hidrato-dicloreto de paraquat exerce efeitos significativos sobre a taxa de crescimento in vitro de uma cepa selvagem da bactéria C. violaceum.

Palavras-chave: Bactéria. Ecossistema. Envenenamento. Toxicidade.
\end{abstract}

Correspondente/Corresponding: *Jane Eyre Gabriel - Universidade Federal do Vale do São Francisco (UNIVASF) - Campus de Ciências Agrárias End: Rodovia BR-407, km 12, Lote 543, Projeto de Irrigação Senador Nilo Coelho, s/n - C1 - CEP-56.300-990 Petrolina, PE - Tel: (87) 21014836 - E-mail: jane.gabriel@univasf.edu.br

\section{INTRODUCTION}

Chromobacterium violaceum is a Gram-negative B-proteobacterium that is completely adjusted to a variety of ecosystems in tropical and subtropical areas, and is especially abundant in the black water and banks of the Rio Negro (Rio Negro basin, with $690000 \mathrm{~km}^{2}$ ) in Amazonia, Brazil (LIMA-BITTENCOURT et al., 2011). The C. violaceum bacterium is exposed to a series of variable environmental conditions in the nature, such as: different sources and abundance of nutrients, changes in temperature and $\mathrm{pH}$, toxic compounds and UV rays, requiring great adaptability and strong protective cellular systems (CHAUDHARI et al., 2014). Notably, several refined mechanisms related to remarkable and exploitable adaptability have been revealed 
in the genome prospecting of this bacterium (BRAZILIAN NATIONAL GENOME PROJECT CONSORTIUM, 2003). Recently, significant effects of the compound paraquat on the activation of a heterologous promoter sequence of pqi genes of $C$. violaceum have experimentally confirmed the inherent existence of regulatory DNA motifs inducible by potent superoxide radical-generating compound paraquat into genome of C. violaceum (GABRIEL et al., 2015). Moreover, some reports in the literature have largely highlighted relevant agricultural and ecological applications of the C. violaceum as agent of biological control of insects, fungi and nematodes in agroecosystems and as bioindicator in the bioremediation processes against heavy metals in contaminated aquatic environments (SOUSA et al., 2019, PRABHAKARAN et al., 2018).

Surprisingly, the compound paraquat dichloride hydrate is the active targeted molecule of the most widely employed toxic herbicides around the world with intensive use and large spatial distribution in the planted area of agricultural crops in all the different Brazilian regions (PIGNATI et al., 2017). At molecular level, the paraquat causes extensive damage to the mitochondria of cells through the production of free radicals and oxidative stress, which results in interrupting important biochemical processes and cell death. In water, the paraquat is adsorbed by particles and sediment and is estimated to have a halflife (under mid-European conditions) between 2 and 820 years depending on the amount of sunlight and depth of water (WATTS, 2011).

As a free-living microorganism, $C$. violaceum is an important member of the fresh water micro flora, participating directly in organic matter decomposition, nutrient cycling and energy flow in the aquatic environment (HIGGINS; HOHN, 2007), and its growth and reproduction are thought to be vulnerable to chemical contaminants. Although some studies have used bacteria as a model organism to evaluate the toxicity of pesticides to the environment, reports on bacterial cellular growth under stressful environmental conditions are still limited. Thus, the purpose of this study was to assess the effect of the compound paraquat dichloride hydrate at different final concentrations and incubation times on the in vitro growth rate of a $C$. violaceum wild type strain.

\section{MATERIALS AND METHODS}

The growth rate of the $C$. violaceum wild type strain ATCC12472 was monitored in a nutrient broth medium to examine its resistance to the compound paraquat dichloride hydrate (36541SKU, Sigma-Aldrich, St. Louis, Missouri, USA). One hundred $\mu L$ of saturated culture obtained from one isolated colony of the $C$. violaceum strain were grown in a selective nutrient broth medium (NB, Difco ${ }^{T M}$, Sparks, Maryland, USA) containing the ampicillin selector antibiotic at a final concentration of $250 \mathrm{\mu g} \mathrm{mL}^{-1}$. Bacterial inocula were incubated in an incubator shaker (model MA420, Marconi Ltda, Piracicaba, Brazil) at $30^{\circ} \mathrm{C}$ for approximately 3 hours under aerated conditions (approximately 250 rpm), until reaching a $0.3 O D_{600 \mathrm{~nm}}$. At this moment, 100 $\mu L$ of paraquat diluted in ultrapure water were added to the bacterial inocula at the final concentrations of 100 and $1,000 \mu \mathrm{g} \mathrm{mL}^{-1}$. In addition, $100 \mu \mathrm{L}$ of ultrapure water were added to the bacterial inoculum in the treatment containing $0 \mu \mathrm{g} \mathrm{mL}^{-1}$ of the compound paraquat and no ultrapure water or paraquat was added to the bacterial inoculum in the control group. Monitoring the bacterial growth rate was based on $O D_{600 n m}$ readings of the spectrophotometer (model SL149, Elico Ltd, Telengana, India) at different incubation times (one, two, three, four, five and 24 hours of incubation). Alternatively, $100 \mu \mathrm{L}$ of the inoculum were removed from each spectrophotometric reading to carry out ten-fold serial dilutions of the samples. Several dilutions were then plated into an agar NB medium to estimate the number of viable bacteria cells in the samples based on colony-forming units (CFU). All of the experimental assays were performed in triplicate. The results, presented as means, standard deviations and standard errors of the means, were statistically estimated using a hierarchical linear model and an analysis of variance was calculated using Tukey's test at 5\% probability.

\section{RESULTS}

Significant decreases in the $C$. violaceum growth rate were detected after one hour of paraquat exposure at a final concentration of $1,000 \mu \mathrm{g} \mathrm{mL}^{-1}(p<0.05)$ compared to all treatments tested (Figure 1). After two hours of incubation, significant decreases were found at all final concentrations of $100(p<0.01)$ and of $1,000 \mu \mathrm{g} \mathrm{mL}^{-1}$ $(p<0.001)$. Moreover, these significant decreases in the C. violaceum growth rate were progressively detected in comparison to other exposure times to the compound paraquat (three, four $1 / 2$ and approximately 24 incubation hours) at final concentrations of $100(p<0.01)$ and 1,000 $\mu \mathrm{mL}^{-1}(p<0.001)$ (Figure 1).

Moreover, lower bacterial growth was also found by counting the total number of colony-forming units under these experimental conditions. Higher total number of colony-forming units $\left(>10^{8} \mathrm{CFU}\right)$ on to nutrient broth agar was counted in the control and $0 \mu \mathrm{g} \mathrm{mL}^{-1}$ samples, whereas these values were significantly lower from two hours up to approximately 24 hours of incubation of paraquat exposure at final concentrations of $100\left(<10^{4} \mathrm{CFU}, p<0.01\right)$ and $1,000 \mu \mathrm{gL} \mathrm{L}^{-1}\left(<10^{2} \mathrm{CFU}, p<0.001\right)$. 
Figure 1 - In vitro growth rate of the Chromobacterium violaceum bacterium in response to compound paraquat dichloride hydrate at different concentrations and incubation times. Results are presented as means, standard deviations and standard errors of the means. Incubation times in hours were randomly selected in 03:15 (zero hour), 04:15 (one hour), 05:15 (two hours), 06:15 (three hours), 07:45 (four hours) and 23:59 (24 hours). The arrow indicates the moment of the addition of the compound paraquat. Significant differences compared to control: ${ }^{*} p<0.05, * * p<0.01, * * * p<0.001$.

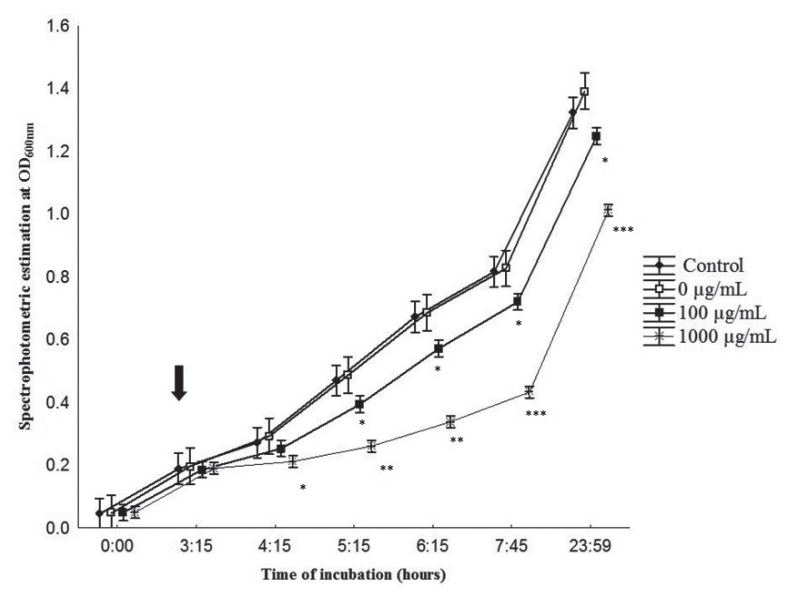

Fonte: Autoria própria

\section{DISCUSSION}

The findings presented in current study indicate that the compound paraquat promotes significant decreases with non-bactericidal effect on the in vitro growth rate of the $C$. violaceum bacterium (Figure 1). A bacteriostatic effect of the paraquat on the growth of Escherichia coli cells was showed during the first 300 minutes of incubation, indicating their extreme sensitivity to this product (BOTELHO; FROES; SANTOS, 2012). One possible mechanism of action of the paraquat might be that this molecule undergoes a single electron reduction with NADPH supplying the necessary reducing equivalents. Further, the paraquat may be reoxidized with the concomitant formation of superoxide anion radicals, resulting in toxicity caused by diminished concentrations of cellular NADPH (DURÁN et al., 2016). Within this context, Halliwell (2000) also speculates that the paraquat reacts rapidly with molecular oxygen generating the toxic radical $\left(\mathrm{O}_{2}\right)$ and activating the superoxide dismutase enzyme that reverses the toxicity of this radical into hydrogen peroxide $\left(\mathrm{H}_{2} \mathrm{O}_{2}\right)$ and water $\left(\mathrm{H}_{2} \mathrm{O}\right)$. Because hydrogen peroxide $\left(\mathrm{H}_{2} \mathrm{O}_{2}\right)$ is also toxic to biological systems, its catalysis promotes the dissociation into $\mathrm{H}_{2} \mathrm{O}$ and $\mathrm{O}_{2}$ and, thus, the paraquat toxicity should not occur. Recently, Lima et al. (2016), examining the proteome response of $\mathrm{C}$. violaceum to $\mathrm{H}_{2} \mathrm{O}_{2}$ found low variation in the expression of specific oxidative stress enzymes because this bacterium exhibits 100 times more catalase activity than other microorganisms. Thus, the elevated baseline production of catalase in this bacterium may provide greater resistance to hydrogen peroxide and activation becomes insignificant under stressful conditions. Within this perspective, such biochemical mechanisms of the compound paraquat seem probably to explain its non-bactericidal effect on the growth rate of the $C$. violaceum bacterium (Figure 1).

Although the $C$. violaceum is an intrinsically well-adjusted bacterium to a wide range of environments due to its great adaptability and refined protective molecular systems, the findings described in current study demonstrate that the herbicide paraquat significantly decreased the in vitro growth rate of a $C$. violaceum wild type (Figure 1). Within this perspective, the $C$. violaceum as a free-living microorganism of the fresh water micro flora with crucial biological role on organic matter decomposition, nutrient cycling and energy flow in the aquatic environments may be deeply affected by polluting waste arising from extensive and indiscriminate use of the paraquat to weed control in the regional agricultural activities. Thus, the significant decreases in the in vitro growth rate of a $C$. violaceum wild type strain in response to paraquat dichloride hydrate strongly indicate that this compound may inhibit molecular events associated with its bacterial growth and reproduction under stressful environmental conditions.

\section{CONCLUSION}

The findings described in current study suggest that the incubation time and dose final concentration of the compound paraquat dichloride hydrate significantly exert effects with drastic reductions on the in vitro growth rate of a C. violaceum wild type strain.

\section{REFERENCES}

BRAZILIAN NATIONAL GENOME PROJECT CONSORTIUM, 2003. The complete genome sequence of Chromobacterium violaceum reveals remarkable and exploitable bacterial adaptability. Proc. Natl. Acad. Sci. U.S.A., Los Gatos, v. 100, p. 11660-11665.

BOTELHO, R. G.; FROES, C. M.; SANTOS, J. B. Toxicity of herbicides on Escherichia coli growth. Braz. J. Biol., São Carlos, v. 72, n. 1, p. 141146, 2012.

CHAUDHARI, V. et al. Effect of certain natural products and organic solvents on quorum sensing in Chromobacterium violaceum. Asian Pac. J. Trop. Dis., Hainan, v. 7S1, p. S204-211, 2014.

DURÁN, N. et al. Advances in Chromobacterium violaceum and properties of violacein-its main secondary metabolite: a review. Biotechnol. Adv., Oxford, v. 34, n. 5, p. 1030-1045, 2016.

GABRIEL, J. E. et al. Heterologous induction of a predicted promoter sequence for paraquat-inducible genes of Chromobacterium violaceum in response to paraquat compound. Braz. J. Biol., São Carlos, v. 75, n. 2, p. 503-504, 2015.

HALLIWELL, B. The antioxidant paradox. Lancet, London, v. 355, n. 9210, p. 1179-1180, 2000.

HIGGINS, J.; HOHN, C. Effects of prevalent freshwater chemical contaminants on in vitro growth of Escherichia coli and Klebsiella pneumoniae. Environ. Pollut., Oxford, v. 152, n. 2, p. 259-266, 2007.

LIMA, D. C. et al. GeLC-MS-based proteomics of Chromobacterium violaceum: comparison of proteome changes elicited by hydrogen 
The compound paraquat dichloride hydrate significantly affects the in vitro growth rate of a Chromobacterium violaceum wild type strain

peroxide. Sci. Rep., London, v. 6, p. 28174, 2016.

LIMA-BITTENCOURT, C. I. et al. Comparative biogeography of Chromobacterium from the neotropics. Antonie Leeuwenhoek, London, v. 99, n. 2, p. 355-370, 2011.

PRABHAKARAN, D. C. et al. Utility of Chromobacterium violaceum SUK1a, an indigenous bacterial isolate for the bioremediation of $\mathrm{Cr}(\mathrm{VI})$. Physicochem. Probl. Mi., Wroclaw, v. 54, n. 4, p. 1266-1281, 2018.

PIGNATI, W. A. et al. Spatial distribution of pesticide use in Brazil: a strategy for Health Surveillance. Cien. Saude Colet., Rio de Janeiro, $v$. 22, n. 10, p. 3281-3293, 2017.

SOUSA, A. J. S. et al. A thermostable chitinase from the antagonistic Chromobacterium violaceum that inhibits the development of phytopathogenic fungi. Enzyme Microb. Technol., New York, v. 126, p. 50-61, 2019.

WATTS, M. Paraquat monograph. $1^{\text {st }}$. Pesticide Action Network Asia \& the Pacific (PAN AP), 2011.

Submetido em: $27 / 02 / 2018$

Aceito em: 26/01/2020 